\title{
Interpretações administrativas
} aderem à lei?

\section{Administrative interpretations of statutory provisions adhere to the statute?}

\author{
Carlos Ari Sundfeld ${ }^{* *}$ \\ Rodrigo Pagani de Souza*** \\ Guilherme Jardim Jurksaitis ${ }^{\star \star *}$
}

RESUMO:

$\mathrm{O}$ artigo analisa como a literatura do direito administrativo vem, ao longo do tempo, tratando a discussão sobre se os costumes (as práticas administrativas) são fonte de direito. Além disso, defende a tese de que a interpretação consolidada pela prática tem de ser considerada parte da própria lei interpretada, para fins da análise da validade dos atos, contratos e processos produzidos durante a vigência da interpretação consolidada. Por fim, o artigo sustenta que, embora, em tese, interpretações consolidadas possam ser revistas para os casos futuros, o intérprete que pretenda alterá-las

\footnotetext{
* Artigo recebido em 14 de março de 2012 e aceito em 21 de maio de 2012.

** Professor da Escola de Direito de São Paulo da Fundação Getulio Vargas (FGV) e da Faculdade de Direito da Pontifícia Universidade Católica de São Paulo (PUC-SP). Doutor e Mestre em Direito pela PUC-SP. Presidente da Sociedade Brasileira de Direito Público (SBDP).

${ }^{* * *}$ Doutor e mestre em direito do Estado pela Universidade de São Paulo, Master of Laws pela Yale Law School (EUA), coordenador do Núcleo de Pesquisas da SBDP.

*** Advogado em São Paulo, mestrando em direito do Estado pela USP, coordenador do Curso de Direito Administrativo da SBDP.
} 
tem um ônus argumentativo suplementar: o de analisar empiricamente as consequências das interpretações consolidadas, provando de modo forte que, no mundo real, essas consequências são negativas. Assim, a motivação que pode levar a uma nova interpretação, contrária à consolidada, não pode ser de caráter exclusivamente abstrato.

\section{PALAVRAS-CHAVE}

fontes do direito - costume - práticas, praxes e precedentes administrativos - interpretações administrativas - abuso de interpretação - declaração de utilidade pública para desapropriação - competência

\section{ABSTRACT}

The article analyses how administrative law theory has been, throughout the times, treating the discussion about whether custom (or administrative practices) is a source of law. Moreover, it defends the thesis that a longstanding statutory interpretation, consolidated by administrative practices, must be considered as a part of the interpreted statute, for the purpose of analyzing the validity of acts, contracts and processes produced while the longstanding interpretation was in force. Finally, the article argues that, although in theory longstanding interpretations can be revised for future cases, the interpreter who intends to revise them has a supplemental argumentative burden: the one of empirically analyzing the consequences of the longstanding interpretation, proving in a strong way that, in the real world, those consequences are, or have been, negative. In this manner, the motivation that can lead to a new, opposing interpretation to the longstanding one, cannot be of an exclusively abstract character.

\section{KEY-WORDS}

sources of law - custom - administrative practices and precedents administrative interpretation - abuse of interpretation - declaration of public utility for expropriation purposes - competence

\section{Introdução}

Neste ensaio discutimos o valor jurídico das práticas administrativas. Indagamos, assim, se ditas práticas podem ser fontes de normas jurídicas. 
Por práticas administrativas nos referimos a interpretações e aplicações reiteradas de normas, num mesmo sentido, consolidadas ao longo do tempo pelos agentes, órgãos e entidades da administração pública.

Que normas são interpretadas e aplicadas por esses atores? Normas que de algum modo tocam à administração pública e suas atividades, ou seja, normas que convencionamos chamar de direito administrativo. Assim, podemos dizer que discutimos aqui o valor das práticas administrativas como fontes de normas de direito administrativo.

A discussão proposta parte de duas simples constatações: a de que o ofício dos administradores públicos é, ou passa por, interpretar e aplicar normas de direito administrativo; e a experiência por eles acumulada, de interpretação e aplicação do direito administrativo, dá forma, com o tempo, a práticas administrativas.

Indagamos: essas práticas têm algum valor jurídico? Noutras palavras: interpretações e aplicações do direito administrativo, consolidadas ao longo do tempo, têm valor como fontes de normas jurídicas?

Em caso positivo, a quem e a quais situações se aplicam as normas derivadas das práticas administrativas? Ainda: a partir de qual momento nascem as normas derivadas dessas práticas?

E estas normas, derivadas das práticas administrativas, têm qual status dentro da hierarquia normativa? Têm força de atos normativos infralegais ou podem, apesar de emanadas da administração pública, aderir à lei e assumir, assim, força de lei?

São estes alguns desdobramentos da mesma indagação central, atinente ao valor jurídico das práticas administrativas.

Não é uma indagação nova. O debate sobre o valor jurídico das práticas, das experiências é o debate sobre o valor jurídico dos costumes. Tem raízes na antiga discussão acerca de quais as fontes do direito e, em especial, qual o lugar dos costumes entre elas. Afinal, os costumes envolvem também aqueles oriundos da administração pública. A eles é comum dar-se o nome de práticas ou praxes administrativas, ou, ainda, precedentes administrativos. Sobre o assunto, cedo se pôs a pergunta: se o costume é fonte do direito, serão as práticas administrativas também fontes do direito administrativo?

Alguns dos primeiros administrativistas brasileiros deram resposta positiva a essa indagação, conforme veremos neste ensaio. E até hoje existem manuais da área que reconhecem as práticas administrativas entre as fontes do direito administrativo. 
Aqui revisitamos o tema, catalogado pelos antigos estudiosos como a questão das fontes do direito administrativo. Mas o problema que se apresenta hoje é distinto do que se pôs em fins do século XIX e início do século XX.

Para eles, parecia importante uma discussão sobre o valor da prática administrativa na ausência de lei. Para nós, já na era da inflação legislativa, o que parece mais proveitoso é discutir o valor da prática administrativa de aplicação das leis. ${ }^{1}$

E, mais do que isso, parece importante refletir sobre o assunto tendo em mira um grande desafio contemporâneo: o de lidar com o problema do abuso de interpretação na prática jurídica, inclusive na área do direito administrativo.

A razão é que constatamos uma perigosa tendência entre os intérpretes e aplicadores do direito público em geral - juízes, administradores públicos, advogados públicos e privados, defensores públicos e membros do Ministério Público - de interpretarem as normas jurídicas à margem da experiência consolidada acerca de sua interpretação e aplicação. É como se, diante da tarefa de interpretar e aplicar textos legais relativamente abertos, o compromisso de cada profissional fosse exclusivamente com as próprias convicções, pouco ou nada importando a experiência acumulada de interpretação e aplicação desses textos (no caso do direito administrativo, pouco ou nada importando as práticas administrativas).

A consequência de tal postura profissional é a adoção, ou propositura, de interpretações absolutamente descompassadas do sentido reiteradamente atribuído às normas. E isso sem quaisquer justificativas, ou sem justificativas suficientes, para enfrentar o ônus argumentativo suplementar necessário à inovação.

Ou pior: sem ao menos a consciência de que, se a experiência importa, o distanciamento dela exige explicações. Afinal, por força dos imperativos da isonomia e da impessoalidade no tratamento dos jurisdicionados e administrados - como diz a Constituição, todos são iguais perante a lei (art. 5ㅇ) e a administração pública obedecerá ao princípio de impessoalidade (art. 37) - , a postura de ignorar a experiência acumulada de interpretação das normas soa abusiva. Para uns se aplica uma interpretação, para outros se aplica uma segunda, e

\footnotetext{
${ }^{1}$ Interessa-nos o costume interpretativo, não o costume introdutório, para usarmos a distinção mencionada em artigo de Carlos S. de Barros Júnior; nas palavras desse autor: "Costume interpretativo é norma secundária, pois regula matéria já disciplinada por meio de lei e se destina a estabelecer a interpretação da norma. O introdutório é norma primária, visto como regula matéria não disciplinada pela lei." BARROS JÚNIOR, Carlos S. de. Fontes do direito administrativo. Revista de Direito Administrativo, Rio de Janeiro, v. 28, p. 7, abr.jun. 1952.
} 
para outros ainda se torna a aplicar a primeira, sem que nada disso constitua constrangimento para que uma terceira seja forjada para outros também todas sacadas do mesmo texto de lei!

Essa oscilação interpretativa no trato de casos idênticos, ao sabor das convicções do intérprete, pode constituir abuso de interpretação. Aqui fazemos um esforço para evidenciar o porquê.

Em suma, nosso objetivo é revisitar a velha questão do valor das práticas como fontes do direito administrativo, com as especificidades de que, no presente estudo, olhamos para a prática administrativa de aplicação das leis (e não para a existente na falta de leis) e estamos atentos ao problema do abuso de interpretação, que parece pervasivo na atualidade.

Um pouco de história ajuda a compreender como chegamos até aqui.

\section{A nossa herança romano-germânica e o estágio da questão no direito administrativo}

Qual a influência das práticas administrativas na edificação do direito administrativo? Acreditamos partilhar com muitos intérpretes a intuição de que há, por certo, alguma influência da experiência na construção jurídica. Não é preciso grande perspicácia para intuir: "-Sim, é claro que a prática influencia na construção do direito! Afinal, o direito é também fruto da experiência, não?".

Mas, para além dessa intuição, parece-nos que o desafio é precisar qual é, exatamente, essa influência. Nesse caso vale recuperar a reflexão já feita pelos administrativistas a respeito do assunto e, a partir dela, considerar o tema à luz dos traços da atualidade, que são a proliferação de leis e o problema do abuso de interpretação.

O tema é antigo; em verdade, remonta pelo menos às origens dos Estados-nação na Europa.

À medida que o Estado-nação foi se afirmando, marcado pelas notas da soberania nacional e do monopólio estatal da produção de normas, um direito legislado ("direito escrito", dizia-se), ditado pelo Parlamento, paulatinamente ganhou espaço face ao direito costumeiro. Lei e costume constituíram assim os dois polos de uma tensão que esteve na origem da nova ordem jurídico-política, a qual suplantaria as encontradas no período medieval.

Nos Estados herdeiros da tradição romano-germânica - como é o caso do Brasil, ao qual a herança chegou por meio do antigo colonizador portu- 
guês - a tensão entre lei e costume resultou na afirmação da supremacia da lei. ${ }^{2}$

O direito legislado de cada Estado-nação, produzido sob a influência do jus commune da Europa medieval (quer dizer, do Corpus Juris Civile de Justiniano e, ainda, do trabalho dos glosadores a partir do final do século XI), foi paulatinamente se afirmando perante os costumes e outros corpos locais de normas. Os costumes locais exerceram alguma influência sobre a produção legislativa de cada Estado-nação, mas esta se manteve essencialmente marcada pela herança romano-germânica.

Já no século XIX, na esteira de uma glorificação do Estado, de um nacionalismo e de um racionalismo crescentes, uma nova nota marcante desse direito legislado passou a ser a edição de códigos - primeiro o Código de Napoleão, em 1804, e, depois, códigos civis em diversos outros países da Europa ocidental. Ainda nos dias de hoje, expressão simbólica da essência romano-germânica dos países herdeiros dessa tradição é o fato de que neles geralmente se encontram cinco códigos básicos: o código civil, o código comercial, o código de processo civil, o código penal e o código de processo penal. ${ }^{3}$

Houve, assim, nos Estados herdeiros da tradição romano-germânica, um significativo esforço de renovação do direito a partir da lei. De maneira que as fontes do direito tradicionalmente reconhecidas nos sistemas jurídicos filiados à família romano-germânica são, basicamente, três: a lei, os regulamentos e o costume, exatamente nessa ordem descendente de autoridade. ${ }^{4}$

\footnotetext{
${ }^{2}$ No Brasil, ilustrativo dessa superação do costume pela lei, já no século XX, foi o Código Civil de 1916 que revogou, por expressa disposição, os costumes concernentes às matérias por ele reguladas. Assim determinava seu último artigo: “Art. 1807. Ficam revogadas as Ordenações, Alvarás, Leis, Decretos, Resoluções, Usos e Costumes concernentes às matérias de direito civil reguladas neste Código". Grifos acrescentados. Esse artigo do código revogado é lembrado por diversos manuais, nas suas passagens sobre as fontes do direito administrativo brasileiro. Cf. MEIRELLES, Hely Lopes. Direito administrativo brasileiro. 2. ed. São Paulo. Revista dos Tribunais, 1966. p. 18; e GASPARINI, Diógenes. Direito administrativo. 13. ed. São Paulo: Saraiva, 2008. p. 31.

${ }^{3}$ Realçamos, aqui, acerca da formação da tradição romano-gernânica e dos papéis da lei e do costume ao longo dessa história, alguns pontos que colhemos do livro dos professores de direito comparado da Universidade de Stanford, na Califórnia: MERRYMAN, John Henry; PÉREZ-PERDOMO, Rogelio. The civil law tradition: an introduction to the legal systems of Europe and Latin America. 3. ed. Stanford: Stanford University Press, 2007. p. 6-19.

${ }^{4}$ Em contraponto, nos sistemas herdeiros da tradição do common law ou anglo-saxônica - a exemplo de Inglaterra, Estados Unidos e Nova Zelândia - , essa hierarquização de fontes não é tão clara e tão rígida. Apresentam este contraponto entre as teorias das fontes do direito nas tradições romano-germânica e anglo-saxônica, em passagem particularmente elucidativa, os autores da obra referida na nota de rodapé anterior: "Para o típico juiz, advogado, ou estudante de direito na França ou na Argentina, a teoria tradicional das fontes do direito representa a verdade básica. Essa é uma parte da ideologia deles. No mundo do common law, por outro lado, que é um mundo menos constrangido pela história peculiar e pelos dogmas racionalistas da Revolução Francesa,
} 
Realmente, no Brasil como noutros países filiados à mesma tradição, o costume é reconhecido como fonte subsidiária do direito. ${ }^{5}$

A repercussão desse reconhecimento na seara específica do direito administrativo brasileiro ocorreu cedo, como já apontado: nossos primeiros administrativistas identificaram os costumes da administração pública como práticas ou praxes administrativas, e arrolaram essas práticas entre as fontes do direito administrativo.

Perceberam, inclusive, que seu objeto de estudo - a administração pública e as normas a seu respeito - era campo fértil para a manifestação dos costumes. Foi o caso de Augusto Olympio Viveiros de Castro, depois ministro do Supremo Tribunal Federal (STF), em seu Tratado de sciencia da administração e direito administrativo publicado em 1906:

Por mais casuísticas que sejam as leis, e por mais minuciosos os regulamentos, é sabido ser um dos característicos da burocracia moderna o amplo esprit de suite, que supre o silêncio da lei e as suas deficiências práticas, por uma tradição peculiar ao próprio corpo dos empregados, em virtude do princípio de que um certo fato se reproduz sempre da mesma maneira, pela simples razão de que sempre se fez assim; e nem há corpo algum de magistratura tão tenazmente aferrado aos precedentes.

Assim, ao lado da ação reflexiva, obra da lei, na ordenação jurídico-administrativa, há uma ação espontânea, cuja forma de condensação é o costume. ${ }^{6}$

atitudes bem diferentes prevalecem. O common law da Inglaterra, um assistemático agrupamento de leis, decisões judiciais e práticas costumeiras, é pensado como a grande fonte do direito. Ele tem profundas dimensões históricas e não é o produto de uma tentativa revolucionária consciente de fazer ou restabelecer o direito aplicável em dado momento da história. Não há nenhuma teoria das fontes do direito sistemática e hierarquizada: legislação, claro, é direito, mas também o são outras coisas, incluindo decisões judiciais. Em termos formais, a relativa autoridade das leis, regulamentos e decisões judiciais pode se apresentar aproximadamente nessa mesma ordem, mas na prática tais formulações tendem a perder sua clareza e sua importância. Advogados do mundo do common law tendem a ser bem menos rigorosos sobre essas matérias que os advogados do mundo da tradição romano-germânica. As atitudes que levaram a França a adotar o sistema métrico, a moeda decimal, os códigos de legislação, e a rígida teoria das fontes do direito, tudo no espaço de uns poucos anos, são ainda completamente estranhas à tradição do common law". Ibid., p. 25-26; tradução livre nossa. ${ }^{5}$ No caso brasileiro vigora a regra segundo a qual, "quando a lei for omissa, o juiz decidirá o caso de acordo com a analogia, os costumes e os princípios gerais de direito", contida no art. $4^{\circ}$ da "Lei de Introdução às normas do Direito Brasileiro" (Decreto-lei no 4.657, 4 de setembro de 1942, alterado pela Lei no 12.376, de 30 de dezembro de 2010).

${ }^{6}$ CASTRO, Augusto Olympio Viveiros de. Tratado de sciencia da administração e direito administrativo. 2. ed. Rio de Janeiro: Jacintho Ribeiro dos Santos Livreiro-Editor, 1912. p. 109 (a primeira edição é de 1906). 
Para este administrativista da Primeira República, portanto, o corpo dos funcionários da administração, mais do que o dos magistrados, seria apegado a práticas e praxes. ${ }^{7}$

Antes, na época do Império, os administrativistas brasileiros iniciaram uma tradição de inserir em seus manuais algum capítulo dedicado à enumeração das fontes do direito administrativo pátrio. ${ }^{8} \mathrm{E}$ os costumes, ainda segundo a tradição, passariam a ser lembrados entre as fontes. É o que se nota em manuais publicados durante a Primeira República (1889-1930) ${ }^{10}$ e,

${ }^{7}$ É comum atribuir-se à "deficiência" da legislação administrativa (querendo-se dizer que é pouco sistematizada, ou não codificada) a razão para a singular importância das praxes ou costumes no direito administrativo. Seja qual for a mola propulsora das práticas administrativas, o fato é que estas foram desde cedo notadas.

${ }^{8}$ Paulino José Soares de Sousa, o visconde do Uruguai - um dos pioneiros da literatura sobre o direito administrativo brasileiro -, inseriu em seu Ensaio sobre o direito administrativo, de 1862, capítulo intitulado "Das fontes, limites e das ciências auxiliares do direito administrativo". Nele enumerou as "fontes do nosso direito administrativo", sem, contudo, referir expressamente o costume entre elas; eis as que mencionou: a) "A antiga legislação portuguesa, até a nossa Independência, que se encontra nas Ordenações, Leis Extravagantes e mais disposições legislativas, compatível com a nossa organização política, e que não tem sido revogada ou alterada por leis posteriores e regulamentos, na parte regulamentar"; b) "A nossa Constituição [de 1824]"; c) "As disposições sobre assuntos administrativos espalhadas nas leis do Império"; e d) "Os decretos, regulamentos e decisões do governo sobre a mesma matéria". CARVALHO, José Murilo de (Org., intr.). Visconde do Uruguai. São Paulo: Ed. 34, 2002. p. 108. (Formadores do Brasil). Fica a indagação: será que por "decisões do governo sobre a mesma matéria", o visconde do Uruguai estava se referindo justamente aos costumes ou às práticas do governo ao decidir? Nesse caso, até para este administrativista do Império os costumes na administração terão sido uma das fontes do direito administrativo, ainda que referidos por outras palavras.

${ }^{9}$ Durante a Primeira República, dois expoentes autores abriram seções de seus manuais dedicadas às "fontes do direito administrativo". Um foi Augusto Olympio Viveiros de Castro, que, em seu Tratado de sciencia da administração e direito administrativo, de 1912 (2. ed.), enumerou como fontes: $a$ ) a Constituição Federal, $b$ ) as leis e decretos legislativos, $c$ ) os decretos, instruções e regulamentos expedidos pelo presidente da República, os avisos, circulares, ordens e portarias dos ministros de Estado, d) os costumes e os princípios gerais de direito e a jurisprudência administrativa. Castro, Tratado de sciencia da administração e direito administrativo, op. cit., p. 111; grifos acrescentados. Outro foi Alcides Cruz, que, no seu Direito administrativo brasileiro, de 1914 (2. ed.), após iniciar ponderando que "as fontes do direito administrativo brasileiro são assaz várias e numerosas", destacou como principais as seguintes: " $a$ ) a Constituição da República; $b$ ) a legislação de direito público que contiver matéria de administração; $c$ ) os decretos regulamentares e os regulamentos em geral contendo matéria de administração; $d$ ) as instruções, os avisos, as circulares e as ordens desse gênero expedidas pelos ministérios; $e$ ) os princípios gerais do direito público e do privado aplicáveis ao direito administrativo; $f$ ) a jurisprudência administrativa nacional especialmente a do Tribunal de Contas; $g$ ) a norte-americana, ex-vi do Dec. oㅡ 848 de 11 de outubro de 1890, art. $387 ;$ h) o costume ou praxe seguida nos negócios públicos; i) a doutrina e a jurisprudência estrangeiras na falta de disposições no direito pátrio". CRUZ, Alcides. Direito administrativo brasileiro. 2. ed. Rio de Janeiro: Francisco Alves e Cia., 1914. p. 27; grifos acrescentados.

${ }^{10}$ Durante a Primeira República, dois expoentes autores abriram seções de seus manuais dedicadas às "fontes do direito administrativo". Um foi Augusto Olympio Viveiros de Castro, que, em seu Tratado de sciencia da administração e direito administrativo, de 1912 (2. ed.), enumerou como fontes: a) a Constituição Federal, $b$ ) as leis e decretos legislativos, $c$ ) os decretos, instruções e re- 
dali em diante, em outros publicados nas décadas de $1930,{ }^{11} 1960,{ }^{12} 1970{ }^{13}$ e $1980 .^{14}$

gulamentos expedidos pelo presidente da República, os avisos, circulares, ordens e portarias dos ministros de Estado, d) os costumes e os princípios gerais de direito e a jurisprudência administrativa. Castro, Tratado de sciencia da administração e direito administrativo, op. cit., p. 111; grifos acrescentados. Outro foi Alcides Cruz, que, no seu Direito administrativo brasileiro, de 1914 (2. ed.), após iniciar ponderando que "as fontes do direito administrativo brasileiro são assaz várias e numerosas", destacou como principais as seguintes: " $a$ ) a Constituição da República; $b$ ) a legislação de direito público que contiver matéria de administração; $c$ ) os decretos regulamentares e os regulamentos em geral contendo matéria de administração; $d$ ) as instruções, os avisos, as circulares e as ordens desse gênero expedidas pelos ministérios; $e$ ) os princípios gerais do direito público e do privado aplicáveis ao direito administrativo; $f$ ) a jurisprudência administrativa nacional especialmente a do Tribunal de Contas; $g$ ) a norte-americana, ex-vi do Dec. oㅡ 848 de 11 de outubro de 1890 , art. $387 ; h)$ o costume ou praxe seguida nos negócios públicos; i) a doutrina e a jurisprudência estrangeiras na falta de disposições no direito pátrio". CRUZ, Alcides. Direito administrativo brasileiro. 2. ed. Rio de Janeiro: Francisco Alves e Cia., 1914. p. 27; grifos acrescentados.

${ }^{11}$ Tito Prates da Fonseca, em seu Direito administrativo, de 1939, após afirmar que "o direito objetivo formal provém, em direito administrativo, das fontes comuns a todo o campo do direito", pondera que "algumas, entretanto, assumem maior destaque no direito em estudo". E passa a tratar daquelas que julga serem as de maior destaque: $a$ ) as leis, que subdivide em "leis formais" e variados tipos de decretos-lei previstos na Carta de 1937; b) as "normas de menor eficácia do que as leis formais", que afirma terem várias denominações, primando a de "regulamento"; e $c$ ) o "costume em direito público". PRATES DA FONSECA, Tito. Direito administrativo. Rio de Janeiro; São Paulo: Livraria Editora Freitas Bastos, 1939. p. 104-122; grifos acrescentados.

${ }^{12}$ Hely Lopes Meirelles, em seu Direito administrativo brasileiro, de 1966 (2. ed., tendo a primeira sido publicada em 1964), observou que "[o] Direito Administrativo abebera-se para sua formação, em quatro fontes principais, a saber: a lei, a doutrina, a jurisprudência e os costumes." Meirelles, Direito administrativo brasileiro, op. cit., p. 16. Oswaldo Aranha Bandeira de Mello, em seu Princípios gerais de direito administrativo, v. I, de 1969, enumerou como "fontes formais objetivas do direito administrativo": $a$ ) as "fontes primárias", assim compreendidas "as imediatas e diretas quanto à revelação do direito positivo em dado Estado-sociedade", cumprindo essa função, no mundo moderno, a "lei"; $b$ ) as "fontes subsidiárias", assim entendidas "as mediatas ou indiretas, pois as primeiras não esgotam o Direito na sua integralidade, e há necessidade das últimas, para supri-las", mencionando como integrantes dessa categoria "o costume, o regulamento e a instrução"; e c) a "fonte complementar", assim considerada "a que, em última instância, fixa o significado das outras duas, em virtude de aplicação delas, e, assim, ou lhes dá o entendimento que se afigura acertado ou, ainda, na falta de texto escrito e de disposição costumeira, constrói direito novo", apontando como tal "a jurisprudência". BANDEIRA DE MELLO, Oswaldo Aranha. Princípios gerais de direito administrativo. 3. ed. São Paulo: Malheiros, 2007. p. 253, grifos acrescentados.

${ }^{13}$ Diogo de Figueiredo Moreira Neto, em seu Curso de direito administrativo (Rio de Janeiro: Forense, 1970), distinguiu entre as "fontes organizadas" do direito administrativo, nelas compreendidas "norma jurídica, doutrina e jurisprudência", e as "fontes inorganizadas", assim entendidos "costume e praxe administrativa". E complementou: "Os princípios não se constituem em fonte autônoma: são doutrinários, quando induzidos, ou são positivados, quando expressos na legislação". Ob. cit., 11. ed. p. 51.

${ }^{14}$ José Cretella Júnior, no seu Direito administrativo brasileiro, v. I, 1983, fez uma síntese das fontes do direito administrativo geralmente apontadas por administrativistas mundo afora, enumerando como tais: $a$ ) a lei, $b$ ) o costume, c) o regulamento, $d$ ) a prática administrativa, $e$ ) a doutrina, $f$ ) a jurisprudência, $g$ ) a analogia, $h$ ) a equidade, $i$ ) os princípios gerais do direito, $j$ ) os tratados internacionais, $l$ ) o estatuto autônomo, editado por entes públicos descentralizados, $m$ ) a instrução e a circular e n) o texto único, "entendido como o ato do poder executivo que reúne e coordena, no mesmo conjunto, as disposições de várias leis sucessivas sobre o mesmo assunto". E, como "prin- 


\section{Alguns tentaram distinguir os costumes das práticas ou praxes administrativas; ${ }^{15}$ ou os costumes dos precedentes administrativos. ${ }^{16}$ Mas a tradição se manteve, em diversos manuais, de fazer ao menos uma alusão ao assunto. \\ Essa tradição reverberaria até mesmo em manuais publicados após a Constituição de 1988, chegando até os dias de hoje ${ }^{17}$ mas seu ponto de infle- xão e início de seu paulatino abandono parece ter ocorrido em 1980. \\ Na maioria dos manuais editados a partir de então, a discussão sobre o papel das fontes continua presente, ainda que sob nova denominação e en-}

cipais fontes do direito administrativo pátrio, em nossos dias", enumerou: $a$ ) a lei, $b$ ) o costume, c) o regulamento, $d$ ) a doutrina, $e$ ) a jurisprudência e $f$ ) o estatuto autônomo. CRETELLA JÚNIOR, José. Direito administrativo brasileiro. Rio de Janeiro: Forense, 1983. v. I, p. 213-232.

${ }^{15}$ Foi este o caso de Diogo de Figueiredo Moreira Neto, que registrou: "Como é sabido, o costume exige dois elementos: o uso e a convicção generalizada da necessidade de sua cogência". E, sobre a "praxe administrativa", afirmou: "Não deve ser confundida com o costume. Falta-lhe a segunda característica acima referida, a opinio juris vel necessitatis, este elemento subjetivo que conduz à sua geral observância". Moreira Neto, Curso de direito administrativo, op. cit., p. 60 (11. ed.). Foi também o caso de José Cretella Júnior, que ponderou que a praxe é das repartições públicas; o costume é do povo. Vejam-se as suas palavras: "Não se deve, entretanto, confundir o costume, propriamente dito, com as chamadas praxes ou práticas administrativas, recurso de que lançam mão com frequência as autoridades administrativas quando, na falta de disposições legais, precisam dar solução a determinado caso submetido à sua apreciação. Ao contrário do costume, que brota espontaneamente do povo, as práticas constituem uma série de usos seguidos pelos funcionários de determinadas repartições diante dos casos concretos que exigem solução imediata, não prevista em lei". Cretella Júnior, Direito administrativo brasileiro, op. cit., p. 219. A distinção foi também anotada por Diógenes Gasparini: "A praxe administrativa (simples rotina administrativa) não se confunde com o costume, não sendo, na opinião da maioria dos autores, fonte do Direito Administrativo". Gasparini, Direito administrativo, op. cit., p. 31.

${ }^{16}$ Oswaldo Aranha Bandeira de Mello distinguiu a praxe ou prática administrativa do precedente administrativo, afirmando que este (precedente) seria fruto da atividade de aplicação de normas pela administração pública, de modo reiterado e uniforme, e aquela (prática) constituiria mera atividade técnica e rotineira da administração, sem o envolvimento de normas jurídicas. Vejam-se as suas palavras: "A praxe administrativa é a atividade interna da Administração, reiterada e uniforme, formando um uso, na aplicação de regras jurídicas normativas e outros atos jurídico-administrativos, criando a rotina administrativa. Não envolve normas jurídicas, mas simples atividade técnica, de prática administrativa, entendida de utilidade, para execução das leis e outros atos jurídico-administrativos. O precedente administrativo é a atividade interna da Administração Pública, reiterada e uniforme, formando a jurisprudência administrativa, no decidir casos individuais, ao aplicar as regras normativas e ao executar outros atos jurídico-administrativos". Bandeira de Mello, Princípios gerais de direito administrativo, op. cit., p. 393. Quer nos parecer que com tais precisões de linguagem o autor apenas detectou diferentes formas de manifestação do costume na administração pública. Salientou que ora o costume se manifesta como prática eminentemente jurídica da administração (p.ex., de interpretação e aplicação de normas), ora como prática eminentemente técnica, sem alusão direta a normas.

${ }^{17}$ Entre os manuais produzidos a partir da década de 1990 que dedicaram atenção específica à enumeração das fontes do direito administrativo, citem-se o de Odete Medauar (Direito administrativo moderno, cuja primeira edição é de 1996 e atualmente está na 16a ${ }^{\prime}$, de 2012), que trata das "formas de expressão do direito administrativo" (cf. p. 41 e ss. na 1. ed.), definindo-as como as 
foque (por exemplo, na abordagem da relação entre o regulamento e a lei), mas a tentativa específica de recensear todas as fontes relevantes para a área, a partir de um olhar voltado à experiência jurídica concreta, caiu em desuso.

A obra de maior influência na adoção dessa nova perspectiva foi Elementos de direito administrativo, de 1980, de Celso Antônio Bandeira de Mello. Com ela inaugurou-se uma nova tradição entre os manualistas brasileiros, consistente em descrever o direito administrativo como um sistema, baseado nalguns princípios fundamentais. Esse sistema passou a ser também descrito como "regime jurídico-administrativo". O autor assim apresentou sua proposta, inovadora à época:

O que importa sobretudo é conhecer o direito administrativo como um sistema coerente e lógico, investigando liminarmente as noções que instrumentam sua compreensão sob uma perspectiva unitária. (...) A este sistema, reportado ao direito administrativo, designamos regime jurídico-administrativo.

Pouco adiante, declarou a sua tese: "Todo o sistema de Direito Administrativo, a nosso ver, se constrói sobre os mencionados princípios da supremacia do interesse público sobre o particular e indisponibilidade do interesse público". ${ }^{18}$ (os itálicos são do original).

Essa nova forma de conhecer o direito administrativo se tornaria muito influente nas décadas subsequentes. A partir dela, a defesa da existência de um "regime jurídico-administrativo", lastreado em "princípios de direito administrativo", constituindo um todo harmônico de normas, reverberaria em diversos dos mais influentes manuais. ${ }^{19}$ Repercutiria até mesmo no texto da

"principais formas mediante as quais o direito administrativo se revela e adquire força impositiva no ordenamento brasileiro" (p. 41) e discriminando, como tais, a Constituição, a lei, os atos administrativos, a jurisprudência e a doutrina (p. 41-44); e o manual de Celso Ribeiro Bastos (Curso de direito administrativo, 2. ed. São Paulo: Saraiva, 1996), que aponta que "o direito administrativo emerge de várias fontes", discriminando como tais a Constituição, a lei e outras espécies normativas com força assemelhada, a jurisprudência e os costumes (p. 14-22).

${ }^{18}$ Bandeira de Mello, Princípios gerais de direito administrativo, op. cit., p. 4-6.

${ }^{19}$ Veja-se, entre tantos outros, o de Maria Sylvia Zanella di Pietro (Direito administrativo: São Paulo: Atlas, 1990), que dedicou capítulo ao "Regime Jurídico Administrativo" (cf. p. 55 e ss.) e, dentro dele, aos "Princípios da Administração Pública" (cf.. p. 57 e ss.). Definiu dito "regime jurídico administrativo" como "o conjunto de traços, de conotações, que tipificam o direito administrativo, colocando a Administração Pública numa posição privilegiada, vertical, na relação jurídico-administrativa" (p. 56) e identificou, como seus princípios fundamentais, o da "legalidade" e o da "supremacia do interesse público sobre o particular", os quais considerou que "(...) não são específicos do direito administrativo porque informam todos os ramos do direito público; no 
Constituição Federal de 1988, cujo art. 37 arrolaria os "princípios da administração pública" ${ }^{20}$

Arriscamos uma explicação sobre o modo pelo qual ocorreu o abandono dessa prática (nesse caso, a doutrinária) no Brasil.

Parece que, em lugar de continuarem a abordar o tema das "fontes do direito administrativo", mais ligado ao contexto em que cada autor examina, de forma um tanto empírica, a experiência jurídica da sua época, os manualistas das décadas de 1980 e 1990 privilegiaram a abordagem do tema dos "princípios de direito administrativo". Foram tomados pela crença no direito administrativo como um sistema racionalmente organizado - que chamaram de "regime jurídico-administrativo" - , lastreado nalguns princípios fundamentais, dos quais derivariam todos os demais princípios e regras. Assim, em lugar da perspectiva histórica ou empirista, tornou-se prevalente a perspectiva sistêmica ou racionalizante na identificação do direito administrativo.

Deveras, descrever o processo de formação do direito administrativo deixou de envolver necessariamente alusões à sua história - e, assim, a um dos aspectos dessa história, que é o papel desempenhado por cada tipo de fonte na construção da experiência jurídica concreta - , tornando-se mais uma questão de declarar quais seus princípios fundamentais e sustentar, a partir daí, que deles teriam derivado todas as normas que o integram.

Desnecessário, por essa segunda perspectiva, se deter muito na discussão sobre quais as formas concretas de expressão do direito administrativo. Afinal, por essa ótica, a origem do direito administrativo se remete em última análise a certos princípios, abstratamente considerados, explícitos ou pressupostos no ordenamento jurídico. É como se as fontes fossem os princípios, não os atos concretamente empregados na produção de normas.

Por certo, a nova abordagem não afirma exatamente isto - que os princípios tais ou quais sejam "fontes do direito administrativo" - , mas lhes

entanto, são essenciais, porque, a partir deles, constroem-se todos os demais" (p. 58). Confira-se também Lúcia Valle Figueiredo (Curso de direito administrativo. 2. ed. São Paulo: Malheiros, 1994), que dedica seção de capítulo inaugural de seu livro ao tema do "regime jurídico-administrativo" (p. 35 e ss.), definindo-o como o "conjunto de regras e princípios a que se deve subsumir a atividade administrativa no atingimento de seus fins" e passando, em seguida, a destacar "alguns princípios essenciais" desse regime (p. 36 e ss.).

${ }^{20}$ Assim dispõe o caput do art. 37 da Constituição de 1988: "Art. 37. A administração pública direta e indireta de qualquer dos Poderes da União, dos Estados, do Distrito Federal e dos Municípios obedecerá aos princípios de legalidade, impessoalidade, moralidade, publicidade e eficiência e, também, ao seguinte: (...)". Trata-se de redação dada pela Emenda oㅡ 19, de 1998, que acresceu ao dispositivo original a menção ao princípio da "eficiência". 
atribui, sem embargo, um papel fundador, de noções centrais, mandamentos nucleares do sistema, como se deles irradiassem por dedução lógica todas as outras normas. Ou seja, princípios não são declarados fontes, mas são tratados como tais.

De certa maneira, reconhece-se a existência das mesmas fontes de sempre - a lei, o regulamento, fala-se bastante também na Constituição, eventualmente nos costumes ou práticas administrativas -, mas investigar como tem sido a experiência concreta de produção de normas a partir desse conjunto de fontes torna-se menos importante do que, digamos, sustentar que as normas de hoje podem ser vistas como dedução lógica de princípios fundamentais.

Apesar de toda a sua notável influência, avaliamos que essa perspectiva sistêmica ou racionalizante de compreensão da formação do direito administrativo tem riscos nada desprezíveis.

Um deles é induzir o intérprete a subestimar o valor das práticas administrativas na edificação do direito administrativo. É que as práticas se formam um tanto a partir da lida concreta das pessoas com o direito, do acúmulo de ações num mesmo sentido em períodos de tempo não muito bem definidos - a partir da experiência jurídica concreta, enfim -, delas derivando normas cuja origem é, portanto, relativamente caótica. Ou seja, das práticas administrativas nascem normas cuja origem é mais caótica do que parece suportar a tese de que o direito administrativo seja um sistema. Aquele que pretenda enxergá-lo como um sistema pode tender a enxergá-las como normas desprovidas de nítidos fundamentos de validade, rejeitando-as.

Outro risco é induzir o intérprete a supervalorizar os princípios e subestimar outras formas de expressão normativa. Ou seja, é fazer o intérprete crer não só que princípios são fontes de direito, mas que bastam para exprimir todo o direito administrativo. Deveras, para aquele que veja o direito administrativo como um sistema, racionalmente organizado, assentado em princípios básicos, mais valerão as deduções feitas a partir desses princípios básicos, tidos como guias de interpretação de todo o sistema, do que as induções derivadas da experiência jurídica concreta com as variadas fontes. Abre-se o caminho para uma postura simplificadora: descobrir o direito administrativo, interpretá-lo e aplicá-lo, tudo isso passa a ser uma questão de manipulação de princípios, não um trabalho prático quotidiano de construção de sentido a partir de um emaranhado de normas oriundas de múltiplas fontes.

Parece necessário, na atualidade, recuperar algo da perspectiva histórica ou empirista de compreensão da formação do direito administrativo. E, des- 
sa perspectiva, em lugar de crer na pura dedução de consequências a partir de princípios, ir fundo na investigação de como as leis, os regulamentos, as resoluções e as portarias e até mesmo as práticas administrativas têm completado normas de conteúdo aberto (inclusive os princípios). Só assim nos aproximaremos do real processo de formação do direito administrativo brasileiro, que se passa diante dos nossos olhos.

Essa perspectiva histórica ou empirista exige do intérprete do direito administrativo uma postura mais investigativa, menos racionalista. Para a construção de sentido a partir de normas de conteúdo mais ou menos aberto, como os princípios (ou quaisquer textos normativos que admitem múltiplas interpretações), importa ao intérprete investigar a experiência de aplicação dessas normas. Muito além do compromisso com as próprias convicções, do intérprete há que se exigir compromisso com a experiência acumulada de interpretação e aplicação do direito, mesmo que seja para superá-la (discutiremos adiante se e como ele pode rejeitar as soluções apontadas pela experiência).

De todo modo, constatada a existência de uma prática administrativa na implementação de lei, o que acontece exatamente? Será possível reconhecer na prática uma fonte de norma jurídico-administrativa de alcance geral?

Voltamos à questão inaugural deste ensaio, ainda sem resposta. Afirmações de que as práticas são fontes do direito administrativo, mais frequentes no passado do que nos dias de hoje (arriscamos diagnosticar o porquê de seu relativo abandono), ainda deixam esta incógnita.

Na produção teórica sobre o direito administrativo brasileiro, a questão ainda é campo relativamente inexplorado. $\mathrm{O}$ entusiasmo doutrinário com os princípios, sobretudo a partir da obra seminal de Celso Antônio Bandeira de Mello, parece tê-la relegado ao segundo plano nas últimas décadas. Não obstante esse fato, a questão do valor jurídico das práticas administrativas continua importante. A razão para tanto é que a legislação parece voltar a valorizar as interpretações administrativas consolidadas pela prática, colocando em tensão, assim, a visão sistêmica ou racionalizante (hoje já dominante na cultura transmitida pelos manuais) com a visão histórica ou empirista do direito administrativo pátrio (que os nossos fundadores adotaram). Ensaiamos algumas reflexões a respeito da questão nesse contexto atual. 


\section{Práticas administrativas como fontes do direito administrativo?}

\subsection{Interpretações administrativas são normas jurídicas}

Uma constatação importante é a seguinte: as interpretações dadas pelas autoridades administrativas aos textos normativos são - elas, as interpretações - normas jurídicas. Como normas, valem para cada caso em que são aplicadas (discutiremos a seguir se valem também como normas gerais, aplicando-se, pois, a outros casos; por hora, fiquemos com a constatação de que são normas para os casos específicos).

$\mathrm{O}$ reconhecimento de que interpretações feitas pelas autoridades competentes são normas encontra-se, antes de tudo, na própria hermenêutica jurídica. Ou seja, a própria teoria de interpretação das normas jurídicas constata que as interpretações, quando emanadas de autoridade competente, têm valor de norma. E parece razoável supor que os "princípios de hermenêutica" aplicam-se às normas de direito administrativo tal e qual se aplicam a normas de outros ramos do direito. ${ }^{21}$ Noutras palavras, o que diz a hermenêutica para o direito como um todo vale também (e por que não?) para o direito administrativo.

Além da hermenêutica, o próprio Supremo Tribunal Federal (STF) tem reconhecido, em sua jurisprudência, por meio da chamada técnica da "interpretação conforme a Constituição", que interpretações são normas. Por essa técnica, diz o Supremo que certa interpretação de texto normativo é a única norma admissível e vigente em virtude da sua especial conformidade com a Constituição Federal, decretando serem inadmissíveis quaisquer outras interpretações porventura concebíveis pelo intérprete. A "interpretação conforme a Constituição" é, portanto, tal como reconhecida pelo STF, uma norma.

\footnotetext{
${ }^{21}$ É o que reconheceu Tito Prates de Fonseca, ao abrir seção intitulada "Interpretação das Leis Administrativas", em seu Direito administrativo, escrevendo: "A doutrina geral da interpretação das leis escapa ao âmbito do direito administrativo. Valem aqui, como no direito em geral, os princípios da hermenêutica, que se aplicam também no departamento em estudo". Prates da Fonseca, Direito administrativo, op. cit., p. 120. No mesmo sentido, Ruy Cirne Lima afirmou: "A interpretação das normas administrativas não deverá reger-se por princípios diversos dos que disciplinam a interpretação das normas jurídicas em geral." CIRNE LIMA, Ruy. Introdução ao estudo do direito administrativo brasileiro. Porto Alegre: Livraria do Globo, 1942. p. 77. E, mais adiante, complementou: "O estudo dos métodos de interpretação excede, porém, aos limites da Ciência do Direito Administrativo. Cabe aqui, apenas, a necessária remissão às exposições autorizadas sobre a matéria" (p. 80).
} 
Para além da hermenêutica e da jurisprudência do Supremo, existem ainda leis que ditam regras que têm como pressuposto a ideia de que interpretações dadas pela administração pública são normas.

Exemplo claro é a regra da vedação à aplicação retroativa de nova interpretação pela Administração Pública, constante do art. 2º parágrafo único, inc. XIII, parte final, da Lei Federal de Processo Administrativo (no 9.784, de 29 de janeiro de 1999). ${ }^{22}$ A interpretação de um texto normativo pela administração pública, à luz dessa regra, constitui norma. Pode vir a ser revogada por nova interpretação, ou seja, por nova norma. E essa nova norma (interpretação) só poderá ser aplicada pela administração pública a situações futuras, jamais retroagindo para apanhar situações anteriores à inovação.

Tal regra colhida da Lei Federal de Processo Administrativo tem pressuposta, portanto, a ideia de que a interpretação de texto normativo pela administração pública constitui, ela própria (interpretação), uma norma.

Outros exemplos de leis que contêm regras com o mesmo pressuposto são as leis orgânicas da advocacia pública; são as leis que organizam as procuradorias municipais, dos estados e do Distrito Federal e, ainda, a que organiza a advocacia da União. Geralmente, são leis que atribuem à chefia dos órgãos de advocacia pública poderes como os de uniformização da jurisprudência administrativa do poder público ou emissão de pareceres sobre matéria jurídica de interesse da administração pública em geral. Tais poderes se expressam mediante atos que, uma vez aprovados pelo chefe do Executivo e oficialmente publicados, tornam-se vinculantes para toda a administração pública em questão. ${ }^{23} \mathrm{Ou}$ seja, também nessas leis orgânicas da advocacia pública está pressuposta a

\footnotetext{
${ }^{22} \mathrm{O}$ texto legal é o seguinte: "Art. 2o A Administração Pública obedecerá, dentre outros, aos princípios da legalidade, finalidade, motivação, razoabilidade, proporcionalidade, moralidade, ampla defesa, contraditório, segurança jurídica, interesse público e eficiência. Parágrafo único. Nos processos administrativos serão observados, entre outros, os critérios de: (...) XIII - interpretação da norma administrativa de forma que melhor garanta o atendimento do fim público a que se dirige, vedada a aplicação retroativa de nova interpretação". Grifos acrescentados.

${ }^{23}$ Consulte-se a Lei Orgânica da Advocacia-Geral da União (Lei Complementar no 73, de 10 de fevereiro de 1993): “Art. 40. Os pareceres do Advogado-Geral da União são por este submetidos à aprovação do Presidente da República: $\S 1^{\circ} \mathrm{O}$ parecer aprovado e publicado juntamente com o despacho presidencial vincula a Administração Federal, cujos órgãos e entidades ficam obrigados a lhe dar fiel cumprimento. $\S 2 \mathrm{O} O$ parecer aprovado, mas não publicado, obriga apenas as repartições interessadas, a partir do momento em que dele tenham ciência". Confira-se também a Lei Orgânica da Procuradoria-Geral do Estado de São Paulo (Lei Complementar estadual no 478, de 18 de julho de 1986, art. 21, incs. I e II, verbis: "Art. 21. São atribuições da Procuradoria Administrativa: I - emitir pareceres em processos sobre matéria jurídica de interesse da Administração Pública em geral; II - propor súmulas para uniformização da jurisprudência administrativa do Estado".
} 
ideia de que interpretações administrativas adotadas de modo formal constituem normas.

Consulte-se também o art. 100, inc. III, do Código Tributário Nacional (Lei no 5.172, de 1966), segundo o qual as "práticas reiteradamente observadas pelas autoridades administrativas" são "normas complementares das leis" em matéria tributária. ${ }^{24}$

Enfim, da hermenêutica jurídica à jurisprudência do STF, passando por diversos exemplares da legislação administrativa, extraem-se evidências de que interpretações administrativas são normas jurídicas. Têm assim força cogente, são respeitadas como normas vigentes e geram efeitos protegidos contra a mudança de interpretação.

Nesse específico sentido, pode-se dizer que as interpretações aderem à lei. Quer dizer, interpretações administrativas de lei consolidadas no passado, que deram ensejo à prática de atos no passado, têm valor de lei em relação a esses casos. O efeito prático disso é que a mudança de interpretação tem de ser entendida como a edição de norma nova, que vale para o futuro, mas não retroage - do mesmo modo que não retroagem as leis novas (pois elas não atingem os casos passados). ${ }^{25}$

\footnotetext{
${ }^{24}$ Este é o exato teor do preceito legal: "Art. 100. São normas complementares das leis, dos tratados e das convenções internacionais e dos decretos: I - os atos normativos expedidos pelas autoridades administrativas; II - as decisões dos órgãos singulares ou coletivos de jurisdição administrativa, a que a lei atribua eficácia normativa; III - as práticas reiteradamente observadas pelas autoridades administrativas; IV - os convênios que entre si celebrem a União, os Estados, o Distrito Federal e os Municípios. Parágrafo único. A observância das normas referidas neste artigo exclui a imposição de penalidades, a cobrança de juros de mora e a atualização do valor monetário da base de cálculo do tributo". Grifos acrescentados.

${ }^{25}$ Questão tormentosa é saber exatamente o que faz com que uma interpretação administrativa se torne consolidada pela prática, de modo que acabe por aderir à lei no específico sentido assinalado, isto é, de modo que produza efeitos de lei relativamente a atos, contratos e processos produzidos durante a sua vigência. Noutras palavras, difícil é saber quais os critérios de identificação de uma interpretação administrativa consolidada pela prática. Um possível indício de que certa interpretação administrativa consolidou-se pela prática é o fato de vir perdurando por algum período, sem oposição (por exemplo, sem sofrer questionamentos na esfera judicial ou administrativa, ou mesmo no âmbito doutrinário). Uma comparação pode ser ilustrativa: para tornar-se consolidada, a interpretação teria que sofrer algo próximo ao que se passa com a posse para converter-se em propriedade na usucapião (art. 1.238 e ss. do Código Civil), ou seja, perdurar por determinado período, sem oposição. E, tal como na usucapião, em que essa posse - por certo período, sem oposição, mansa e pacífica - converte-se em domínio, a interpretação administrativa de lei havida reiteradamente, por certo período, sem oposição, acabaria convertida em algo mais firme, consolidado, aderente à lei.
} 


\subsection{Das práticas administrativas não necessariamente derivam normas de caráter geral}

Resta saber se interpretações consolidadas na prática administrativa, por autoridades públicas que reiteradamente as apliquem, constituem normas cogentes apenas para os casos específicos em que aplicadas no passado, ou, na realidade, geram normas de alcance geral, aplicáveis a um número indefinido de pessoas e situações no futuro.

Posta ainda de outra forma, a questão é: havendo interpretação aplicada no passado não apenas em um único caso, mas incorporada à prática administrativa, é possível tratá-la como uma norma geral para os casos futuros?

Deixemos a indagação em suspenso por um momento e reflitamos.

Por um lado, a administração pública pode, em princípio, superar suas atuais interpretações. A regra que veda a aplicação retroativa de nova interpretação, constante da Lei Federal de Processo Administrativo, pressupõe a possibilidade, justamente, de uma nova interpretação administrativa. A administração pública não parece vinculada eternamente, para os casos futuros, a interpretações adotadas como práticas administrativas em casos pretéritos.

Por outro lado, quer nos parecer que, em princípio, nova interpretação administrativa, diversa da adotada como prática, só poderá valer para novos casos; não poderá desconstituir atos e relações jurídicas do passado, arrimados justamente na prática posteriormente revista.

Mesmo para casos novos, a mudança de interpretação consolidada pela prática não é trivial. A existência de práticas administrativas traz um ônus argumentativo suplementar aos intérpretes que decidam contrariá-las em casos novos. É inadmissível que o juiz de direito, ou o administrador público, decida uma matéria sem levar em consideração a experiência acumulada de interpretação e aplicação da legislação envolvida. Em função de experiências consolidadas como práticas administrativas, é exigível do juiz e do administrador, como critério de suficiência de motivação, que examinem casos semelhantes à luz dessa experiência - por exemplo, que comparem o caso vertente com os que formaram a experiência, que examinem o contexto atual diante da experiência etc. Decidir contrariamente a uma prática administrativa exige especialíssimas razões.

Feitas essas considerações concluímos, em suma, que, embora não seja possível extrair, automaticamente, normas gerais para casos futuros das práticas administrativas passadas, essas devem operar para o juiz de direito e para 
o administrador público com grande força, impondo-lhes um ônus argumentativo suplementar para que inovem e adotem novas interpretações. E, ainda, novas interpretações porventura adotadas somente produzirão efeitos para o futuro, sem desconstituir atos e relações jurídicas do passado.

\subsection{A superação de práticas administrativas por administradores públicos e juízes exige fundamentação clara e explícita, que discrimine razões suficientemente fortes para a superação, sob pena de invalidade por abuso de interpretação}

Parece-nos relevante acentuar a existência deste ônus argumentativo suplementar para o intérprete oficial, juiz de direito ou administrador público, que pretenda superar uma interpretação aplicada como prática administrativa.

O ônus suplementar de argumentação é a resposta que encontramos para a seguinte indagação: pode o intérprete oficial, chamado a aplicar um texto de lei em um caso novo, optar por certa interpretação a partir de argumentação construída apenas em abstrato, como se inexistisse a experiência histórica de aplicação do texto? Pode desvincular-se por completo da interpretação que historicamente tem sido dada ao texto pela administração pública, ignorando a história?

Parece-nos que não - o juiz de direito, ou o gestor público, não tem liberdade para, diante da lei que admita, em tese, mais de uma interpretação plausível, desconsiderar a interpretação administrativa que historicamente tem sido adotada e simplesmente sacar, de uma interpretação em abstrato da lei, outra interpretação.

Noutras palavras, tudo indica que é vedado ao intérprete oficial da lei argumentar apenas em abstrato, como se a experiência administrativa inexistisse. A decisão assim tomada configuraria abuso de interpretação.

Por outro lado, ele poderia até rechaçar a interpretação administrativa consolidada pela prática e adotar, pois, uma mudança de interpretação, desde que atendido este ônus argumentativo suplementar.

Por exemplo, a justificativa para uma mudança de interpretação jamais poderia ser o temor abstrato dos efeitos da interpretação vigente. Afinal, a interpretação vigente, por afigurar-se consolidada, já terá produzido efeitos concretos, que devem ser concretamente considerados. Se já existir, pois, uma interpretação administrativa consolidada de texto legal, não caberá con- 
frontar duas interpretações em abstrato, como se uma delas já não tivesse sido testada.

A existência da prática administrativa eleva o ônus argumentativo do intérprete oficial para decidir contrariamente à interpretação encampada pela prática. As formas pelas quais ele pode atender às exigências desse ônus são variadas. Pode, por exemplo, confrontar o caso vertente com as características da prática administrativa, apontando-lhe as nuanças que porventura o tirem da "vala comum" e justifiquem a nova interpretação. Pode ainda encontrar justificativa para a nova interpretação numa mudança do contexto do caso presente, diante dos contextos que informaram a prática até então consolidada. Pode até evidenciar, por alguma maneira, que a prática consolidada é um erro jurídico monumental.

Enfim, são múltiplas as formas ao seu alcance para dialogar com a experiência; mas o que não pode o intérprete oficial fazer, sob pena de incorrer em abuso de interpretação, é ignorá-la. Tem de confrontar-se com a experiência historicamente sedimentada pela administração pública e aceita por todos aqueles que o precederam.

\subsection{A lei pode definir quais os efeitos de interpretações adotadas na prática administrativa e até atribuir-lhes efeitos gerais}

Embora das práticas administrativas não nasçam, automaticamente, normas de alcance geral para os casos futuros, uma lei pode vir a disciplinar os efeitos de normas adotadas nas práticas administrativas e, até mesmo, defini-las como de alcance geral. Nesse caso, juízes de direito e autoridades administrativas têm de acatá-las.

Há muitas leis que regulam - ou modulam, como se diz - os efeitos jurídicos de interpretações administrativas havidas em casos específicos. Embora não sejam as leis em si que atribuam efeitos jurídicos às interpretações dadas pelas autoridades administrativas competentes, são elas que frequentemente modulam seus efeitos. Leis podem definir, por exemplo, se interpretações administrativas terão efeitos gerais e a partir de quando surtirão efeitos gerais.

É o que fazem as aludidas leis sobre processo administrativo, advocacia pública e administração tributária. Vejamos.

A Lei Federal de Processo Administrativo, por sua regra de vedação da aplicação retroativa de nova interpretação, regula a produção de efeitos da nova interpretação no tempo. 
As leis orgânicas da advocacia pública, por suas regras sobre o parecer do procurador ou advogado geral aprovado pelo chefe do Executivo, definem quem é alcançado pela interpretação aprovada (em regra, toda a administração pública, mas não as autoridades dos outros poderes).

E o Código Tributário Nacional, por sua regra que define as "práticas administrativas" como "normas complementares das leis", também define quem é alcançado pelas interpretações adotadas na prática da administração tributária. Ao estabelecer que tais práticas complementam as leis, está reconhecendo implicitamente que têm alcance geral, para o Estado e os particulares, como as leis.

3.5 É importante que a administração pública publique enunciados normativos que sintetizem quais as normas derivadas de práticas administrativas, definindo seus exatos teor e alcance

As incertezas envolvidas no tratamento do costume como fonte do direito já foram destacadas por Ruy Cirne Lima, na seguinte passagem: "A lei demonstra-se por uma prova pré-constituída: - a publicação; o costume pode depender de prova casual. O conteúdo da lei é certo; o do costume, incerto" ${ }^{26}$

Ainda comparando o costume com a lei enquanto fontes do direito, Cirne Lima ponderou:

Traduz-se nesse conflito das fontes o conflito dos métodos de cognição jurídica.

Da lei, deduz-se a norma jurídica; do uso, é preciso induzi-la. Renova-se, destarte, na Ciência do Direito, o velho conflito entre o método dedutivo e o método indutivo. ${ }^{27}$

Realmente, não há como negar que a derivação de uma norma geral, por indução, a partir de uma prática administrativa envolve incertezas, e que a fixação do sentido e alcance dessa norma e, bem assim, do exato momento a partir do qual passa a vigorar, podem ser na realidade muito problemáticas.

\footnotetext{
${ }^{26}$ Cirne Lima, Introdução ao estudo do direito administrativo brasileiro, op. cit., p. 44-45.

${ }^{27}$ Ibid., p. 46-47.
} 
Assim, ainda que uma lei atribua efeitos gerais (mais amplos ou menos amplos, conforme o caso) a interpretações adotadas na prática administrativa, é útil que as autoridades administrativas publiquem, por exigência legal ou iniciativa própria, enunciados normativos que formulem resumidamente quais as interpretações extraídas da prática, definindo-lhes exatos teor e alcance.

A publicação desses enunciados normativos é fator relevante para a promoção da segurança jurídica. Enunciados do gênero importam para determinar, primeiro, que da prática administrativa nasceu uma norma geral e, segundo, qual é o exato sentido e alcance dessa norma.

Por isso são relevantes as regras constantes de leis da advocacia pública, prevendo a edição de "súmulas para uniformização da jurisprudência administrativa" e enunciados semelhantes.

\subsection{Existem casos em que a interpretação administrativa adere em definitivo à lei, exigindo intervenção legislativa para ser modificada?}

Por fim, podemos indagar se uma interpretação derivada da prática administrativa, reconhecida por lei como norma geral, pode aderir em definitivo à lei, isto é, galgar um degrau na hierarquia das normas e adquirir força de lei, tornando-se, pois, vinculante para juízes e administradores públicos para todos os casos futuros. Ou seja: haveria uma hipótese de interpretação administrativa com força de lei - com força superior, portanto, à de um ato infralegal - para casos futuros?

Um fenômeno assim poderia ocorrer? Será isto que sugeriu nas entrelinhas a observação de Hely Lopes Meirelles, a respeito dos costumes como fonte de "poderosa influência" no direito administrativo brasileiro? Escreveu ele:

No Direito Administrativo Brasileiro o costume exerce poderosa influência, em razão de deficiência da legislação. A prática administrativa vem suprindo o texto escrito, e, sedimentada na consciência dos administradores e administrados, a praxe burocrática passa a suprir a lei, ou atua como elemento informativo da doutrina. ${ }^{28}$

\footnotetext{
${ }^{28}$ Meirelles, Direito administrativo brasileiro, op. cit., p. 18.
} 
Tão "sedimentada na consciência dos administradores e administrados" estaria a prática administrativa que, assim, supriria a lei, talvez no sentido de adquirir força de lei também para o futuro?

As consequências seriam relevantes. Se aderisse à lei desse modo, a interpretação administrativa reconhecida como norma geral só poderia ser alterada por intervenção do legislador, não mais do juiz de direito ou do administrador público.

Dita aderência, contudo, parece-nos implausível. Os administradores públicos não estão eternamente acorrentados às interpretações administrativas do passado. Porém, reconhecemos a força acumulada por interpretação administrativa constante, reiterada, sedimentada por anos - talvez décadas a fio - de uma mesma lei, e considerada norma geral, de sorte a impor à autoridade administrativa que decida superá-la um elevadíssimo ônus argumentativo.

E mais: quer nos parecer que a adoção de nova interpretação, pela autoridade pública, substituindo interpretação consolidada no passado, só valerá para o futuro, não produzindo efeitos desconstitutivos de atos e relações jurídicas do passado. O intérprete oficial não pode anular interpretação generalizada, mas apenas revogá-la.

Em caso de adoção de nova interpretação, a aderência à lei da interpretação revogada existirá apenas para que fiquem preservados seus efeitos quanto aos casos passados, não aos futuros. Noutras palavras, o juiz de direito e o administrador público, ao se depararem com interpretação generalizada adotada como prática pela administração pública, só dispõem do futuro; os efeitos por ela (interpretação) produzidos no passado, estes terão de respeitar. É como se as interpretações generalizadas, incorporadas à prática administrativa, pudessem, sim, ser revogadas, mas seus efeitos passados estivessem "acima" do alcance do intérprete - grudados, pois, à lei.

As reflexões aqui ensaiadas estão longe de constituírem uma palavra final sobre esta fascinante questão do valor das práticas administrativas como fontes de normas jurídico-administrativas. Os casos concretos podem ajudar a testá-las e, quem sabe até, reformá-las ou invalidá-las.

\section{A prática de desapropriações estaduais em favor de empreendimentos federais}

Um caso que ajuda a entender como as práticas administrativas podem se configurar atina a certo modo consolidado de interpretação e aplicação da Lei de Desapropriações brasileira. 
Cuida-se de velho diploma, de presença obrigatória nas coletâneas da legislação administrativa brasileira - o Decreto-lei no 3.365, de 21 de junho de 1941. Também denominado Lei de Desapropriações, ele dispõe sobre as chamadas desapropriações por utilidade pública. É um diploma nacional, aplicável a desapropriações pelas administrações públicas de todos os níveis de nossa federação (União, estados, Distrito Federal e municípios).

Diante dele, propomos a seguinte questão: pode o chefe do Executivo, de certo ente da federação, emitir declaração de utilidade pública de imóvel, para fins de desapropriação ou instituição de servidão em favor de atividades sujeitas à competência administrativa de outro ente da federação?

Um governador de Estado pode expedir decreto expropriatório de imóveis para, digamos, a construção de um aeroporto, o que equivale a desapropriar em favor do serviço de infraestrutura aeroportuária, que é da competência da União (art. 21, XII, c, da CF)? Pode ainda, sobre dado imóvel, instituir servidão para a passagem de linhas de transmissão de energia elétrica, que integram um serviço também da alçada federal (art. 21, XII, $b$, da CF)? Pode o prefeito municipal instituir servidões, sobre determinados imóveis, em favor de serviços locais de gás canalizado, que são da competência do Estado (art. $25, \S 2$, da CF)?

Enfim, os casos ilustram a questão que, de outro modo, poderia ser posta assim: pode um ente da federação desapropriar bens em favor de atividade da incumbência de outro?

Consultando o Decreto-lei oㅡ 3.365/1941, não se encontra uma resposta explícita. A questão não foi nele diretamente resolvida. Nada foi dito sobre eventual cooperação entre os entes da federação em matéria expropriatória.

A disposição que mais se aproxima da nossa dúvida é a do art. 6o, que define a competência dos chefes de Executivo para declararem bens de utilidade pública para fins de desapropriação ou, nos termos do art. 40, para instituírem servidão. Vejam-se:

Decreto-lei no 3.365, de 1941

Art. 6o A declaração de utilidade pública far-se-á por decreto do Presidente da República, Governador, Interventor ou Prefeito.

(...)

Art. 40. O expropriante poderá constituir servidões, mediante indenização na forma desta lei. 
Em abstrato, duas interpretações do art. 6o parecem razoavelmente defensáveis: uma, que chamaremos aqui de interpretação ampla, é a que admite declarações de utilidade pública não apenas em prol de atividades afetas à competência administrativa do declarante, mas também, de modo ampliado, em prol de tudo aquilo que está afeto a outras esferas da federação; a outra, que chamaremos de interpretação restrita, é a que proíbe declarações em prol de atividades afetas a outros entes da federação e admite somente as que beneficiem atividades próprias do declarante.

Ou seja, pela interpretação ampla dir-se-á que, como o art. 6o não especificou em prol de quem o decreto expropriatório pode ser emitido, admitiu implicitamente a possibilidade de sua emissão em prol de múltiplos empreendimentos, federais, estaduais ou municipais. O prefeito pode decretar a desapropriação de bem em favor de serviço público estadual, ou o governador em favor de serviço público municipal, ou ambos (governador ou prefeito) em favor de atividade regulada pela União, e assim por diante. O silêncio legal terá significado ausência de impedimentos a possíveis iniciativas expropriatórias de um ente da federação em cooperação com outro ente da federação. Como esta cooperação é desejável no federalismo brasileiro, por que não o seria em matéria expropriatória?

De outro ângulo, agora em prol da interpretação restrita, alguém dirá que o silêncio legal terá significado o oposto: simplesmente que cada chefe de Executivo deve se ater a emitir declarações para desapropriações ou servidões em favor de atividades necessariamente de sua alçada - ou seja, do próprio ente que representa. Desse modo, o prefeito só poderá desapropriar em favor de atividades afetas ao município; o governador, das que estiverem afetas ao estado; e o presidente da República, das que couberem à União ou ao âmbito nacional como um todo. Assim, todos, em princípio, se manteriam estritamente ligados às suas esferas de atuação. Se esta é a regra, por que não o seria em matéria expropriatória?

Talvez esta segunda interpretação (a restrita) tenha até mais apelo intuitivo que a primeira (a ampla). É que a restrita parece cingir-se ao lugar comum, isto é, à intuição de que alguém desapropria para realizar, por óbvio, os seus próprios cometimentos, e não os dos outros. Já a ampla exige enxergar no silêncio da lei, associado ao federalismo de cooperação delineado pela Constituição de 1988, toda uma construção de ideias que não estão ali estampadas explicitamente, com absoluta clareza. Numa construção de algum apelo, é preciso demonstrar que há uma diretriz constitucional de cooperação, que irradia efeitos sobre a Lei de Desapropriações, a qual não previu a coopera- 
ção explicitamente, mas que, justamente por ter de ser interpretada à luz da Constituição, deve ser lida como um texto legal que admite desapropriações em prol de empreendimentos da alçada de distintos entes da federação. Ou seja, trata-se de construção algo trabalhosa.

Pois a prática administrativa de interpretação e aplicação da Lei de Desapropriações poderá surpreender aqueles que, sem conhecê-la, isto é, fiando-se apenas em seu texto cru, suponham-na restrita.

Veja o leitor que, diante dessas duas interpretações abstratamente defensáveis do mesmo texto legal, constatamos que milita em favor da ampla uma prática administrativa já bastante consolidada, ao longo dos 70 anos de aplicação do Decreto-lei no 3.365/1941.

Trata-se da prática de vários estados desapropriarem, ou instituírem servidões, em favor de serviços públicos federais ou atividades sujeitas à regulação federal.

É uma experiência administrativa relevante, que pode ser ilustrada por incontáveis exemplos ao longo da nossa história.

Realmente, desde há várias décadas, os governadores de Estado vêm entendendo, com base nesse art. 6º, que possuem competência para desapropriar ou instituir servidões em favor de atividades definidas constitucionalmente como serviços públicos federais (tais como serviços de geração, transmissão e distribuição de energia elétrica, de telecomunicações, portuários e aeroportuários) ou atividades sob competência regulatória federal (como dutos de combustível ou de minérios). A circunstância de haver lei setorial específica prevendo a competência do Executivo federal para editar atos relativos a desapropriações ou servidões setoriais (p. ex., leis do setor elétrico) não tem sido considerada como óbice à atuação concorrente dos estados em relação a esses setores.

Por isso, os governadores têm editado, por décadas, decretos de declaração de utilidade pública para desapropriações ou servidões em favor de distintos serviços públicos federais ou atividades sob competência regulatória da União. Há exemplos nas décadas de 1970, 1980, 1990 e primeira década do século XXI, em estados como São Paulo, Minas Gerais, Bahia e Paraná.

No caso paulista, o governador já declarou de utilidade pública, para fins de desapropriação ou servidão, áreas destinadas à instalação de linhas de transmissão e de distribuição de energia elétrica, ${ }^{29}$ a certo apoio a empreendi-

${ }^{29}$ Cf. Decreto sem número de 18-2-1970, Decreto no 2.590, de 9-10-1973, Decreto no 7.135, de 26-111975 e Decreto no 38.033 , de 9-12-1993. 
mento de geração de energia elétrica, ${ }^{30}$ à instalação de torres de transmissão de sinais VHF e, ainda, à construção e ampliação de aeroportos (aeroportos de Guarulhos, Campinas, Indaiatuba e Ibiúna). ${ }^{31}$

No Estado de Minas Gerais, o governador declarou de utilidade pública, para fins de desapropriação ou servidão, terrenos necessários à instalação de linhas de transmissão e distribuição de energia elétrica, ${ }^{32}$ à infraestrutura de apoio a uma usina hidrelétrica ${ }^{33}$ e à instalação de estações de transmissão de sinais $\mathrm{VHF}^{34}$ e de micro-ondas. ${ }^{35}$ É de Minas, ainda, um exemplo de declaração de utilidade pública de certa área em favor de empresa privada, para a passagem de mineroduto. ${ }^{36}$

No estado da Bahia, o governador declarou de utilidade pública, para fins de desapropriação, área destinada à implantação de um novo porto, denominado "Porto Sul", no município de Ilhéus. ${ }^{37}$

No estado do Paraná, o governador declarou de utilidade pública, para fins de desapropriação e constituição de servidão, áreas necessárias à instalação de poliduto de transporte de combustíveis. ${ }^{38}$

A peculiaridade desse caso de expropriação em favor do poliduto, como se pode notar, está em que nele se trata da instalação de infraestrutura para exercício de atividade econômica (transporte de combustíveis) sob a competência regulatória da União; não, propriamente, para a prestação de serviço público federal. Nisso se assemelha ao caso da servidão em prol do mineroduto, em que estava em pauta não a prestação de serviço público federal, mas certamente o desempenho de uma atividade sob a responsabilidade da União (em vista da sua titularidade sobre os bens minerais a serem escoados pelo duto).

De todo modo, a quantidade de exemplos, em variadas épocas e distintos contextos, relativamente a variados serviços públicos e até mesmo atividades sob regulação ou responsabilidade federal, constitui robusta evidência de que a prática administrativa nos estados brasileiros tem sido a de uso de seus po-

\footnotetext{
${ }^{30}$ Cf. Decreto no 14.574 , de 27-12-1979.

${ }^{31}$ Cf. Decreto no 5.498, de 15-1-1975, Decreto no 6.724, de 15-9-1975, Decreto no 5.573, de 30-1-1975, Decreto n⿳0 18.985, de 9-6-1982 e Decreto no 40.196, de 17-7-1995.

${ }^{32}$ Cf. Decreto no 13.223, de 3-2-1970, Decreto no 13.208, de 1-12-1970, Decreto no 15.772, de 10-101973, Decreto no 24.626, de 15-4-1985, Decreto no 24.805, de 11-7-1985, Decreto oㅡ 39.771, de 27-71998 e Decreto no 40.536 , de 14-8-1999.

${ }^{33}$ Cf. Decreto no 40.426 , de 9-7-1999.

${ }^{34}$ Cf. Decreto no 13.857, de 26-8-1971 e Decreto no 24.097, de 28-11-1984.

${ }^{35}$ Cf. Decreto no 16.681 , de 24-10-1974.

${ }^{36}$ Cf. Decreto sem número, de 3-11-2008.

${ }^{37}$ Cf. Decreto no 12.352 , de 25-8-2010.

${ }^{38}$ Cf. Decreto no 9.159, de 29-12-2010.
} 
deres expropriatórios para fins de cooperação com a realização de empreendimentos de titularidade ou competência da União. ${ }^{39}$

Ademais, nos casos, também inúmeros, em que a efetivação da medida tem exigido processo judicial, os Judiciários estaduais vêm aceitando com naturalidade esses decretos estaduais como base da desapropriação ou da instituição de servidão. Não se encontra contestação ou discussão jurisprudencial a esse respeito.

Exemplo, no Tribunal de Justiça do Estado de São Paulo (TJ/SP), é a Apelação no 658.428.5/5-00-Campinas, 6ª Câmara de Direito Público, rel. des. José Habice, j. 18-8-2008, em que uma ação de apossamento administrativo ou desapropriação indireta discutia os efeitos desencadeados por "(...) decretos da lavra do Governador do Estado [que] declararam de utilidade pública considerável área de terra próxima ao Aeroporto de Viracopos (...)" (excerto do voto do rel. des. José Habice), abrangendo a propriedade da autora. Em nenhum momento discutiu-se, no acórdão, a competência estadual para expedir decretos declarando de utilidade pública áreas necessárias à expansão da infraestrutura do serviço aeroportuário federal.

Há outros exemplos provenientes do tribunal paulista ${ }^{40} \mathrm{e}$, também, do Tribunal de Justiça do Estado de Minas Gerais (TJ/MG). ${ }^{41}$

Em todos os casos colacionados, a ação girava em torno de desapropriação ou instituição de servidão administrativa, ao amparo de decretos esta-

\footnotetext{
${ }^{39}$ Isso não tem excluído, por óbvio, iniciativas do presidente da República de declarar de utilidade pública, para fins de desapropriação, bens necessários à prestação dos serviços públicos federais. Para referir simples exemplo no setor elétrico, confira-se o Decreto Federal sem número de 30-71993, pelo qual o presidente da República “[d]eclara de utilidade pública, para fins de instituição de servidão administrativa, em favor da Companhia Paulista de Força e Luz - CPFL, a área de terra que menciona". O exemplo ilustra o ponto que procuramos aqui salientar: verifica-se, de fato, o exercício de competência concorrente dos chefes de Executivo dos entes da federação para decretar a desapropriação ou a instituição de servidão relativamente a imóveis que servirão, em última análise, a atividades da alçada federal.

${ }^{40}$ Cf. Apelação no 7.045.0870-6 (Benedita Aparecida de Oliveira Santos e Outro × Companhia de Transmissão de Energia Elétrica Paulista - CTEEP), rel. des. Mauro Conti Machado, 19a Câmara de Direito Privado, j. 17-8-2009; AI no 793.971-5/8-00 (Companhia de Transmissão de Energia Elétrica Paulista - CTEEP $\times$ Espólio de Lauro Morandi e Outros), rel. des. Thales do Amaral, $4^{\mathrm{a}}$ Câmara de Direito Público, j. 9-8-2008; e Apelação n 9089659-28.2004.8.26.0000 (Nelson Ferreira da Costa e S/M $\times$ Companhia de Transmissão de Energia Elétrica Paulista - CTEEP), rel. des. Alvez Bevilacqua, 2a Câmara de Direito Público, j. 21-6-2011.

${ }^{41}$ Cf. Apelação no 1.0701.99.006954-7/001 (Cemig Cia. Energética Minas Gerais × Diamantino Silva Filho e Outro(a)(s)), rel. des. Maria Elza, 5a Câmara Cível, j. 20-11-2008; AI no 1.0023.10.0001454/001 (José Veriano Gomes e Outro(a)(s) × Codemig - Cia. de Desenvolvimento Econômico de Minas Gerais), rel. des. Silas Vieira, $3^{a}$ Câmara Cível, j. 12-8-2010; e AI nº 1.0460.06.020981-0/001 (Francisco Carlos Fleming e Outro(a)(s) $\times$ Cemig Cia. Energética Minas Gerais), rel. des. Silas Vieira, 8a Câmara Cível, j. 23-11-2006.
} 
duais, em benefício de um serviço público federal ou atividade regulada pela União, sem que, no entanto, a competência do estado para decretá-las suscitasse qualquer controvérsia nos acórdãos. Ao contrário, a competência estadual parece ter sido encarada com naturalidade.

São, portanto, exemplos ilustrativos de importante constatação: o fato de que os Judiciários estaduais aceitam e processam com naturalidade ações movidas com base em decretos estaduais, com vistas à desapropriação ou à servidão de áreas para a constituição do patrimônio necessário à prestação de serviços públicos federais ou atividades econômicas sob regulação federal. Noutras palavras, as administrações estaduais declaram áreas como "de utilidade pública" em prol da constituição de patrimônio, via desapropriação ou servidão, para empreendimentos da alçada federal, e no momento da execução judicial dessas medidas os Judiciários estaduais aceitam esse fato com tranquilidade.

Some-se a isso o fato de que, na jurisprudência do Superior Tribunal de Justiça (STJ), é firme o entendimento de que a mera circunstância de o objeto de uma ação envolver desapropriação para a constituição de infraestrutura de serviço público federal não atrai, automaticamente, o interesse da União no feito. Muito menos implica que haveria interesse exclusivo da União na desapropriação.

A jurisprudência do STJ aceita que a União simplesmente não participe, não intervenha, nos processos de desapropriação para a constituição do patrimônio necessário a prestação de serviços públicos federais. Para o STJ - ainda noutras palavras - , a União não é parte necessária em litígios envolvendo a constituição desse patrimônio. Em muitos casos, a própria União não quer participar do processo. E isso é encarado como normal. ${ }^{42}$

Tal jurisprudência, ao reconhecer que a União não é parte necessária nas demandas que envolvam a constituição do patrimônio indispensável à prestação de serviços federais, revela-se consentânea com a conclusão de que outros atores podem estar empenhados nesse objetivo. Por que não figurariam,

\footnotetext{
${ }^{42}$ São exemplos dessa jurisprudência os seguintes julgados do STJ: REsp no 146.855-SP (União $\times$ Eletricidade de São Paulo S/A. - Eletropaulo), rel. min. Garcia Vieira, 1aㅡ Turma, j. 7-11-1997; REsp no 160.617-SP (União $\times$ Eletricidade de São Paulo S/A. - Eletropaulo), rel. min. Milton Luiz Pereira, 1a Turma, j. 1-3-2001; REsp no 135.876-SP (União × Eletricidade de São Paulo S/A - Eletropaulo), rel. min. João Otávio de Noronha, 2a Turma, j. 7-12-2004; Conflito de Competência ${ }^{\mathrm{o}}$ 47.620-SP (Eletropaulo Eletricidade de São Paulo S/A × União, rel. min. Denise Arruda), 1로 Seção, j. 22-2-2006; Conflito de Competência no 110.237-RS (Ceran Companhia Energética Rio das Antas $\times$ Pozza S/A Industrial Moveleira e Outros), rel. min. Castro Meira, 1르 Seção, j. 28-4-2010.
} 
entre esses atores, justamente os estados, em harmonia com o federalismo de cooperação? Isso, de fato, tem ocorrido.

Em suma, os Judiciários estaduais encaram com naturalidade as iniciativas expropriatórias estaduais em prol de serviços públicos federais e, em sintonia com tal postura, o STJ não exige automaticamente a presença da União nos processos judiciais (muito menos supõe que exista interesse exclusivo da União nesses processos).

Uma nuança dessa prática pode, por derradeiro, ser destacada. Trata-se de prática estabelecida em casos em que a desapropriação ou servidão favorecia, sobretudo, empresas estatais, normalmente controladas pelo próprio estado. Há, porém, casos em que também empresas do setor privado, exploradoras de atividades sob regulação federal, foram beneficiadas pelos decretos estaduais. Os dois casos destacados acima foram o do estado de Minas, de instituição de servidão para a instalação de mineroduto por empresa da iniciativa privada (Decreto estadual sem número, de 3-11-2008), e o do estado do Paraná, de desapropriação ou instituição de servidão para a instalação de poliduto de transporte de combustíveis, também por empresa do setor privado (Decreto estadual no 9.159, de 29-12-2010). Ainda um terceiro exemplo pode ser mencionado. Trata-se de conjunto de empresas privadas, consorciadas com empresa estatal, beneficiadas por decreto do governador do estado de Minas Gerais, que declarou a utilidade pública de bens a serem expropriados em favor de empreendimento do setor elétrico (Decreto estadual sem número, de 13-9-2000).

Assim, além da maior abundância de exemplos de decretos estaduais em favor de empresas estaduais prestadoras de serviços públicos federais, também há casos que ilustram a prática estadual de declarações de utilidade pública em favor de empresas do setor privado, que exploram atividades sob a regulação federal (poliduto de combustíveis e mineroduto) ou prestam serviço público federal delegado (setor elétrico).

A interpretação que tem sido aceita pelas práticas administrativa e judicial é, portanto, no sentido de que a competência para a declaração de utilidade pública conferida aos Governadores pelo art. 6을 do Decreto-lei n⿳o 3.365/1941 inclui os casos em que o serviço ou a atividade beneficiada envolva titularidade ou competência federal.

Pois bem. Para que, apesar de toda essa experiência de interpretação e aplicação do art. 6o da Lei de Desapropriações, a administração ou o Judiciário passem a, daqui para diante, em novos casos, sem mudança de lei, entender inviáveis as desapropriações estaduais ou municipais em favor de serviço federal 
ou regulado pela União, não nos parece que baste alguma motivação abstrata, ainda que inteligente e racional. Seria preciso muito, muito mais do que isso. Seria preciso demonstrar concretamente, analisando as consequências práticas da interpretação consolidada, que ela tem efeitos negativos fortes, empiricamente verificáveis. É isso o que chamamos de ônus argumentativo suplementar.

Nessa hipótese, então, seria exigível do juiz ou do administrador, como critério de suficiência de motivação, que examinasse o caso à luz da prática existente - por exemplo, que o comparasse com os passados, que examinasse seu contexto diante do que a experiência sedimentada informou ao longo dos anos etc. A prática administrativa identificada tem de ser levada a sério, impondo ao novo intérprete um ônus argumentativo suplementar para que inove e, assim, inadmita desapropriações do gênero por incompetência da autoridade expropriante.

Assim, não poderá simplesmente sacar outra interpretação da Lei de Desapropriações com base, por exemplo, no temor abstrato do reconhecimento da competência dos governadores de estado. Não poderá concluir pela vedação de desapropriações estaduais em favor de empreendimentos federais só com o argumento de que essas iniciativas estaduais levariam ao caos administrativo, à desordem, a uma multiplicidade de desapropriações pelos estados somente para assegurarem boas relações com o governo federal. Afinal, existe uma experiência administrativa estadual de longa data, que comprova justamente o contrário - que os estados têm desapropriado reiteradamente em prol de empreendimentos federais e isto não tem levado a caos administrativo algum, a desordem alguma.

\section{Conclusão}

O exemplo mostra que, acerca de uma questão bem palpável de interpretação administrativa de lei, as duas distintas perspectivas sobre o direito administrativo podem ser decisivas. Como vimos a partir da análise de um pouco da história da literatura brasileira da área, os compromissos fundamentais do intérprete podem ser muito diferentes. E, nesse exemplo, nota-se que tais compromissos podem gerar consequências importantes na hipótese de o intérprete decidir contrariar interpretação administrativa consolidada pela prática.

De um lado, constatamos a visão histórica ou empirista, que os fundadores do direito administrativo brasileiro aparentemente adotaram. A enumeração 
das fontes do direito administrativo que faziam - entre elas, as práticas administrativas - denotava uma visão do direito como uma construção empírica, não como uma construção puramente racional.

De outro lado, identificamos a visão sistêmica ou racionalizante, que ganhou corpo a partir da década de 1980. Na dedução do que é direito, feita por meio do trabalho de interpretação, passaram então a valer mais as abstrações derivadas dos princípios básicos do sistema, e menos as construções germinadas da prática.

Emergiram ao longo da nossa história, portanto, duas visões distintas sobre o direito administrativo. Pois, hoje, nesse exemplo, quanto mais confortável estiver com a visão racionalizante, o intérprete talvez se sinta mais propenso a dar ao art. 6o da Lei de Desapropriações interpretação assentada em noções abstratas, de forma um tanto alheia aos 70 anos de práticas administrativas estaduais ligadas à matéria. Quanto mais identificado com a visão empirista, por outro lado, mais o intérprete se verá compelido a reconhecer valor na interpretação da lei consolidada pelas práticas administrativas estaduais.

Ambas as visões do direito administrativo, a empirista e a racionalizante, parecem se opor como tendências em conflito na atualidade. A razão é que as próprias normas vêm valorizando, nalguma medida, a construção empírica do direito, em contraponto a construções puramente racionais.

Exemplo é a Lei Federal de Processo Administrativo, que combate excessos da visão racionalizante com a vedação da aplicação retroativa de nova interpretação. É certo que assim ela não resolveu o problema de se saber quais as condições para a mudança de interpretação vigente; todavia, deixou claro que, havendo mudança, a nova interpretação só valerá para casos futuros. Noutras palavras, estabeleceu a regra de que as interpretações administrativas de lei consolidadas pela prática não retroagem. Têm valor, portanto, as interpretações consolidadas pela prática, ainda que possam ser superadas por nova interpretação, que se aplicará somente a casos futuros.

A mudança de interpretação administrativa é uma situação ideal para se testar o compromisso do intérprete com uma ou outra visão do direito administrativo. E, ao arbitrar o conflito entre as duas visões nesta situação, a Lei Federal de Processo Administrativo parece ter rechaçado soluções baseadas apenas em interpretações abstratamente admissíveis de um texto normativo, privilegiando as que respeitem a história concreta da sua aplicação. Mudar interpretação administrativa consolidada pela prática, segundo a Lei Federal de Processo Administrativo, exige respeito aos efeitos já produzidos no passado; a força da nova convicção do intérprete oficial só alcança o futuro. 
Terá a lei imposto, assim, uma visão mais empirista do direito administrativo a uma cultura que se tornou sobremodo encantada com o paradigma racionalizante? Cremos que sim. Todavia, essa lei não é fundamental para a defesa de que o abandono das interpretações consolidadas, ainda que para casos futuros, não pode ocorrer com base em pura construção abstrata de sentido, dependendo necessariamente de uma análise da experiência. Essa defesa tem fundamento em certa ideia de direito - a visão empirista - que se opõe à outra - a visão puramente racionalizante.

A diferença de uma para outra, no que agora nos importa, está no valor que dão à experiência no debate sobre a interpretação jurídica de uma norma.

Os racionalistas tendem a se sentir mais livres para a construção puramente abstrata de sentido para os textos legais, confiantes que são na capacidade de os sistemas (que são construções abstratas) gerarem respostas mais adequadas para os problemas. Já os empiristas acreditam menos nesses sistemas concebidos pelas abstrações lógicas, e valorizam mais as lições da experiência, para rejeitar ou acolher como boa uma solução.

Neste ensaio, fizemos o elogio de uma visão empirista e, a partir dela, sustentamos que o abandono de interpretações consolidadas, se não é impossível, não pode, todavia, ocorrer na base da simples concepção de uma solução abstratamente melhor. Nosso argumento, portanto - de orientação empirista -,é que, para ser adotada, a nova solução tem de enfrentar o teste do confronto com o mundo real, em que a interpretação passada já foi testada, já produziu efeitos e já pode ser avaliada quanto a suas qualidades e defeitos práticos.

Defendemos, em suma, um método de decisão muito comprometido com a experiência, pois é ele que nos parece compatível com um direito administrativo não platônico.

\section{Referências}

BANDEIRA DE MELLO, Oswaldo Aranha. Princípios gerais de direito administrativo. 3. ed. São Paulo: Malheiros, 2007 (1. ed.: 1969).

BANDEIRA DE MELLO, Celso Antônio. Elementos de direito administrativo. 1. ed., 2. tir. São Paulo: Revista dos Tribunais, 1981 (1. tir.: 1980).

BARROS JÚNIOR, Carlos S. de. Fontes do direito administrativo. Revista de Direito Administrativo, Rio de Janeiro, v. 28, p. 1-9, abr./jun. 1952. 
BASTOS, Celso Ribeiro. Curso de direito administrativo. 2. ed. São Paulo: Saraiva, 1996.

CIRNE LIMA, Ruy. Introdução ao estudo do direito administrativo brasileiro. Porto Alegre: Livraria do Globo, 1942.

CRETELLA JÚNIOR, José. Direito administrativo brasileiro. Rio de Janeiro: Forense, 1983. v. I.

CRUZ, Alcides. Direito administrativo brasileiro. 2. ed. Rio de Janeiro: Francisco Alves e Cia., 1914.

GASPARINI, Diógenes. Direito administrativo. 13. ed. São Paulo: Saraiva, 2008.

DI PIETRO, Maria Sylvia Zanella. Direito administrativo. São Paulo: Atlas, 1990.

FIGUEIREDO, Lúcia Valle. Curso de direito administrativo. 2. ed. São Paulo: Malheiros, 1995 (1. ed.: 1994).

MEDAUAR, Odete. Direito administrativo moderno. São Paulo: Revista dos Tribunais, 1996.

MEIRELLES, Hely Lopes. Direito administrativo brasileiro. 2. ed. São Paulo: Revista dos Tribunais, 1966 (1. ed.: 1964).

MERRYMAN, John Henry; PÉREZ-PERDOMO, Rogelio. The civil law tradition: an introduction to the legal systems of Europe and Latin America. 3. ed. Stanford: Stanford University Press, 2007.

MOREIRA NETO, Diogo de Figueiredo. Curso de direito administrativo. Rio de Janeiro: Forense, 1970.

PRATES DA FONSECA, Tito. Direito administrativo. Rio de Janeiro; São Paulo: Livraria Editora Freitas Bastos, 1939.

SOARES DE SOUSA, Paulino José (Visconde do Uruguai). Ensaio sobre o direito administrativo (1862). In: CARVALHO, José Murilo de (Org.; intr.). Visconde do Uruguai. São Paulo: Ed. 34, 2002. (Formadores do Brasil)

VIVEIROS DE CASTRO, Augusto Olympio. Tratado de sciencia da administração e direito administrativo. 2. ed. Rio de Janeiro: Jacintho Ribeiro dos Santos Livreiro-Editor, 1912 (1. ed.: 1906). 
Decretos citados

ESTADO DE SÃO PAULO. Decreto sem número de 18-2-1970; Decreto no 2.590, de 9-10-1973; Decreto no 5.498, de 15-1-1975; Decreto oㅜ 5.573, de 30-11975; Decreto no 6.724, de 15-9-1975; Decreto o 7.135, de 26-11-1975; Decreto no 14.574, de 27-12-1979; Decreto no 18.985, de 9-6-1982; Decreto no 38.033, de 9-12-1993; Decreto no 40.196, de 17-7-1995.

ESTADO DE MINAS GERAIS. Decreto no 13.223, de 3-2-1970; Decreto no 13.208, de 1-12-1970; Decreto no 13.857, de 26-8-1971; Decreto no 15.772, de 10-10-1973; Decreto o 24.097, de 28-11-1984; Decreto ํo 24.626, de 15-4-1985; Decreto no 16.681, de 24-10-1974; Decreto o 24.805, de 11-7-1985; Decreto no 39.771, de 27-7-1998; Decreto oㅡ 40.426, de 9-7-1999; Decreto no 40.536, de 14-81999; Decreto sem número, de 13-9-2000; Decreto sem número, de 3-11-2008.

ESTADO DA BAHIA. Decreto no 12.352 , de 25-8/2010.

ESTADO DO PARANÁ. Decreto no 9.159, de 29-12-2010.

Acórdãos citados

TRIBUNAL DE JUSTIÇA DO ESTADO DE SÃO PAULO: Apelação no 658.428.5/5-00-Campinas, 6a Câmara de Direito Público, rel. des. José Habice, j. 18-8-2008; Apelação no 7.045.0870-6, rel. des. Mauro Conti Machado, 19a Câmara de Direito Privado, j. 17-8-2009; AI no 793.971-5/8-00, rel. des. Thales do Amaral, 4a Câmara de Direito Público, j. 9-8-2008; Apelação no 908965928.2004.8.26.0000, rel. des. Alvez Bevilacqua, 2a Câmara de Direito Público, j. 21-6-2011.

TRIBUNAL DE JUSTIÇA DO ESTADO DE MINAS GERAIS: Apelação no 1.0701.99.006954-7/001, rel. des. Maria Elza, 5a Câmara Cível, j. 20-11-2008; AI no 1.0023.10.000145-4/001, rel. des. Silas Vieira, 3 a Câmara Cível, j. 12-8-2010; AI no 1.0460.06.020981-0/001, rel. des. Silas Vieira, 8a Câmara Cível, j. 23-11-2006.

SUPERIOR TRIBUNAL DE JUSTIÇA: REsp no $146.855-S P$, rel. min. Garcia Vieira, $1^{a}$ Turma, j. 7-11-1997; REsp no 160.617-SP, rel. min. Milton Luiz Pereira, 1a Turma, j. 1-3-2001; REsp no 135.876-SP, rel. min. João Otávio de Noro- 
nha, 2aㅡ Turma, j. 7-12-2004; Conflito de Competência no 47.620-SP, rel. min. Denise Arruda, 1aㅡ Seção, j. 22-2-2006; Conflito de Competência no ${ }^{\circ}$ 110.237-RS, rel. min. Castro Meira, 1ํㅗㅡ Seção, j. 28-4-2010. 